\title{
CARACTERISTICS OF PNEUMONIA HOSPITALIZATIONS AT PEDIATRIC CLINIC TUZLA
}

\author{
Hadzic Devleta, Zulic Evlijana \\ Pediatrics clinic, University Clinical Center of Tuzla, Bosnia and Herzegovina
}

Primljen/Received 29. 01. 2015. god.

Abstract: Introduction: Pneumonia is the most serious inflammatory disease of the lower respiratory system caused by various microorganisms. It occurs in all age groups, more often in children aged 5 years and below, in children with chronic diseases and impairments of the immune status. The aim of this study was to present the epidemiological, etiological and clinical characteristics of pneumonia in hospitalized children. Patients and methods: We analyzed the epidemiological, etiological and clinical characteristics of pneumonia in 224 children hospitalized at the Pediatric hospital Tuzla during one year period with radiologically proven pneumonia. Results: Almost half of children with pneumonia (46.4\%) were infants, and $82.1 \%$ of patients were under five years of age. The boys were leading in all age groups. A significant number of children had one or more predisposing risk factors. Clinical signs, gas analyses and pulse oximetry well correlated with hypoxemic type of respiratory failure. The most frequently isolated pathogens were Staphylococcus aureus, Klebsiella sp. and Pseudomonas aerugino$s a$. The average length of intensive treatment was 2.8 days and the average total length of treatment was 9.5 days. Conclusion: Pneumonia hospitalizations of children at the Pediatric Clinic Tuzla, showed the usual age and gender distribution. A significant number of children had underlying chronic diseases. Etiological characteristics emphasizing severity of disease and immune status of children. The management of pneumonia in children has to follow general pediatric principles, and special attention should be given to risk categories.

Key words: characteristics, pneumonia hospitalization, children, etiology, prevalence.

\section{INTRODUCTION}

Pneumonia is one of the most common causes of childhood mortality worldwide, especially among those under 5 years of age. Although, mortality is lower in
Prihvaćen/Accepted 01. 03. 2015. god.

developed countries, pneumonia in children is still associated with substantial morbidity and remains the most common indication for hospitalization outside the newborn period. Also, it is one of the most costly pediatric diseases (1).

Classification of pneumonia in children is not unique. Today generally accepted classification is community-acquired pneumonia, nosocomial pneumonia and pneumonia in patients with impaired immunity (2). The spectrum of clinical presentations is wide: from mild to life-threatening cases. Risk of severe infections is particularly big in infants and preschool children. The severe pneumonia is defined with the presence of fever, respiratory distress and/or dehydration (3). Simple pneumonia may evolve into complicated pneumonia, characterized by the development of parapneumonic effusions, empyema, pyopneumothorax, or necrotizing pneumonia. There are differences between recently published guidelines in terms of the clinical criteria of severity of pneumonia, although all of the experts agreed that hypoxemia is the most important parameter for decision making process (4). On the basis of clinical signs, laboratory and radiographic examinations, it is very difficult to distinguish between bacterial and viral pneumonia. On the basis of epidemiological, clinical, radiological, and laboratory findings we are able to identify pathogens and implement optimal treatment.

The incidence of pneumonia in general population is determined by the climate, epidemic trends, age, immunisation status, and immune competence (5). In developed countries, approximately $10-15$ children per 1000 are diagnosed with community-acquired pneumonia and one-to-four per 1000 are admitted to hospital yearly (6). Hospital admissions in resource-rich countries for pneumonia in children increased during the 1990's and early 2000's (6). As a result, pediatric pneumonia is often the focus of epidemiological studies 
and research outcomes and serves as an ideal target for quality benchmarking and improvement efforts (3).

The aim of this study was to show epidemiologic, etiologic and clinical characteristics of pneumonia in hospitalized children at the Pediatric hospital Tuzla.

\section{METHODS}

Medical records of 224 children, treated for pneumonia at the Paediatric hospital in Tuzla during the one-year period (from January 2014 to the end of December 2014), were retrospectively analysed. We analyzed the medical history, clinical and laboratory findings, therapeutic procedures, length of intensive care, length of total treatments and their outcomes. From the medical history data age, gender, and general pediatric findings were analyzed. Also, leading clinical signs and symptoms were analyzed which included: local auscultatory findings, vital parameters such as pulse rate, respiratory rate, body temperature, and blood oxygen saturation. Blood oxygen saturation was measured by pulse oximetry. Laboratory parameters which were analyzed included: erythrocytes sedimentation rate full blood count, hematocrit, C-reactive protein, and gas analysis. Radiographic lung findings and microbiological analyzes of the blood, throat and nasal swabs were done. Further, therapeutic procedures such as the application and the length of oxygen therapy, drug ain inhalation therapy (bronchodilators), antibiotic therapy, administration of systemic corticosteroids, the need for other supportive care, bronchoscopy, and surgical drainage,.The length of treatment and outcome of each treatment were monitored and included in the analyses. For statistical analysis results applied standard methods of descriptive statistics, used statistical program Arcus QuicStat and Systat software.

\section{RESULTS}

In 2014, about 332 children (208 boys (62.7\%) and 124 girls $(37.3 \%)$ respectively, were hospitalized and treated for the lower respiratory tract infections at the Pediatric hospital Tuzla. About 224 (67.5\%) children had radiologicaly proven pneumonia, and about 31 $(9.3 \%)$ of children had pulmonary atelectasis as a complication of pneumonia. The boys were numerically dominated in all age groups. Almost half of children with pneumonia (46.4\%) were infants, and $82.1 \%$ of children were under 5 years of age. Pneumonia was bilateral in 102 children (45.5\%), right-sided in $100(44.6 \%)$ and left- sided in 22 children (9.8\%) (Figure 1).

A large number of patients had one or more predisposing factors (Table 1).

Pneumonia in hospitalized children was clinically manifested with signs of dyspnea, tachypnea, tachycar-

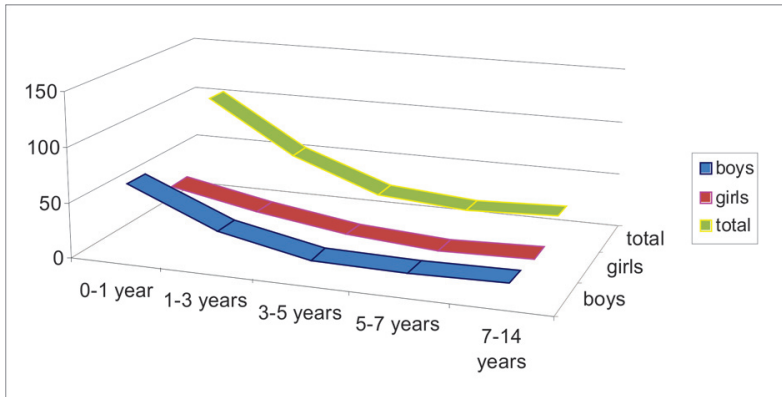

Figure 1. Age and gender distribution of children treated for pneumonia

Table 1. The presence of risk factors for pneumonia in treated children

\begin{tabular}{|l|c|}
\hline \multicolumn{1}{|c|}{ Risk factors } & n (\%) \\
\hline Immunodeficiency & $16(7.1)$ \\
\hline Anemia & $100(44.6)$ \\
\hline Congenital heart defects & $24(10.7)$ \\
\hline Neuromuscular Disease & $5(2.2)$ \\
\hline Neurodevelopmental disorders & $28(12.5)$ \\
\hline Tracheostomy & $3(1.3)$ \\
\hline Cystic fibrosis & $2(0.9)$ \\
\hline
\end{tabular}

dia and hypoxemia leading to imminent respiratory failure. The vital parameters of children with pneumonia in this study are presented in the following table (Table 2).

Table 2. Vital signs in patients with pneumonia

\begin{tabular}{|c|c|c|c|c|c|}
\hline Age (years) & & $0-1$ & $1-3$ & $3-7$ & $7-14$ \\
\hline \multirow{4}{*}{$\begin{array}{c}\text { Heart rate } \\
\text { (per minute) }\end{array}$} & minimum & 126 & 120 & 120 & 100 \\
\cline { 2 - 6 } & maximum & 160 & 150 & 136 & 144 \\
\cline { 2 - 6 } & mean & $\mathbf{1 4 6 . 7}$ & $\mathbf{1 3 6}$ & $\mathbf{1 2 4 . 3}$ & $\mathbf{1 2 0 . 6}$ \\
\hline & normal & $110-160$ & $100-140$ & $95-120$ & $60-110$ \\
\hline \multirow{4}{*}{$\begin{array}{c}\text { Respiratory } \\
\text { rate } \\
(\text { per minute) }\end{array}$} & minimum & 26 & 42 & 24 & 10 \\
\cline { 2 - 6 } & maximum & 65 & 60 & 52 & 48 \\
\cline { 2 - 6 } & mean & $\mathbf{4 9 . 3}$ & $\mathbf{4 7 . 6}$ & $\mathbf{3 6}$ & $\mathbf{2 9 . 4}$ \\
\cline { 2 - 6 } & normal & $30-40$ & $25-30$ & $20-25$ & $15-20$ \\
\hline
\end{tabular}

The vital parameters (heart rate and respiratory rate) in children with pneumonia were higher in relation to the normal values for their age. Table 3 shows the parameters of acid-base status and gas analysis in children with pneumonia.

Clinical signs, gas analyses and oxygen saturation, correlated well with hypoxemic type of respiratory failure.

Basic laboratory tests results such as full blood count, erythrocyte sedimentation rate, and C-reactive protein (CRP) values are presented in Table 4. 
Table 3. Gases analysis in patients with pneumonia

\begin{tabular}{|l|c|c|c|c|}
\hline \multicolumn{1}{|c|}{ Parametar } & $\begin{array}{c}\text { Mean } \\
\pm \mathrm{SD}^{*}\end{array}$ & Minimun & Maksimum & Median \\
\hline $\mathrm{pH}$ & $7.35 \pm 0,07$ & 7.08 & 7.47 & 7.35 \\
\hline $\mathrm{pCO} 2(\mathrm{kPa})$ & $4.99 \pm 0.96$ & 2.64 & 7.49 & 4.9 \\
\hline $\mathrm{pO2}(\mathrm{kPa})$ & $6.62 \pm 1.27$ & 3.59 & 8.6 & 6.85 \\
\hline Base excess & $-2.4 \pm 4$ & -14 & 2.5 & -1.4 \\
\hline $\begin{array}{l}\text { Bicarbonates } \\
\text { (mmol/l) }\end{array}$ & $21 \pm 3.6$ & 10 & 28 & 21.25 \\
\hline $\begin{array}{l}\text { Oxygen } \\
\text { saturation }(\%)\end{array}$ & $78 \pm 12$ & 45.2 & 90 & 80 \\
\hline
\end{tabular}

* mean \pm standard deviation

Table 4. Biochemical parameters in patients with pneumonia

\begin{tabular}{|l|c|c|c|c|}
\hline \multicolumn{1}{|c|}{ Parametar } & $\begin{array}{c}\text { Mean } \\
\pm \text { SD* }^{*}\end{array}$ & Minimun & Maksimum & Median \\
\hline $\begin{array}{l}\text { Erythrocyte } \\
\text { sedimentat. }\end{array}$ & $33 \pm 27$ & 5 & 110 & 30 \\
\hline $\begin{array}{l}\text { C-reactive } \\
\text { prot. (mg/L) }\end{array}$ & $37 \pm 56$ & 0.1 & 249 & 17.5 \\
\hline $\begin{array}{l}\text { Hemoglobin } \\
(\mathrm{g} / \mathrm{L})\end{array}$ & $116 \pm 16$ & 75 & 148 & 119 \\
\hline $\begin{array}{l}\text { Erythrocytes } \\
(\mathrm{x} 1012 / \mathrm{L})\end{array}$ & $4.23 \pm 0.52$ & 3.2 & 5.4 & 4.2 \\
\hline $\begin{array}{l}\text { Leukocytes } \\
(\mathrm{x} 109 / \mathrm{L})\end{array}$ & $14.4 \pm 5.4$ & 5.2 & 27 & 13.7 \\
\hline $\begin{array}{l}\text { Hematocrit } \\
(\mathrm{L} / \mathrm{L})\end{array}$ & $0.34 \pm 0.04$ & 0.27 & 0.40 .34 & \\
\hline
\end{tabular}

* mean \pm standard deviation

Out of 224 children with radiologically confirmed pneumonia, about 100 children had CRP value above 10 $\mathrm{mg} / \mathrm{l}$ on admission. Leukocytosis above 15 x 109 / 1 was found in 76 children. About 67 children were febrile at the hospital. Admission analysis of microbiological findings showed positive throat swab cultures in 47 children, in 41 children positive nasal swabs cultures, and eight children ain had positive blood cultures (Figure 2).

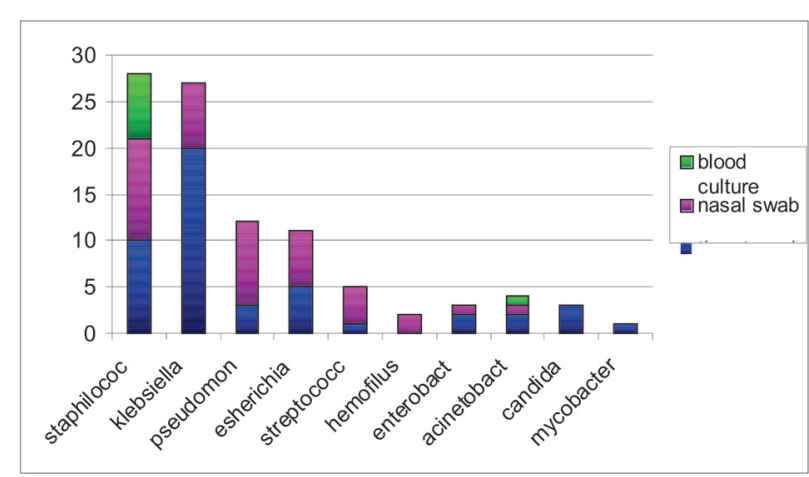

Figure 2. Pathogens isolated in patients with pneumonia
The most frequently isolated pathogens were Staphylococcus aureus, Klebsiella sp. and Pseudomonas aeruginosa.

Among other therapeutic procedures intensive supervision, monitoring of vital parameters and oxygen therapy were required. Parenteral antibiotics were administered to 207 children (92.5\%). Bronchodilators and intensive respiratory physiotherapy were applied in almost all children. Cardiotonics were required and administered to 61 children $(27.4 \%)$. The largest of children (44) who had signs of congestive heart failure and required cardiotonics and diuretics were infants. The medical treatment of pneumonia in hospitalized children is given in Table 5 and it shows the various degrees of severity of the disease in the treated children.

Table 5. Therapeutical treatment in patients hospitalized for pneumonia

\begin{tabular}{|l|c|}
\hline \multicolumn{1}{|c|}{ Treatment } & N (\%) \\
\hline Monitoring & $104(46.4)$ \\
\hline Oxygen Therapy & $128(57.1)$ \\
\hline Rehydration & $185(82.6)$ \\
\hline Bronchodilators & $210(93.7)$ \\
\hline Respiratory physiotherapy & $198(88.4)$ \\
\hline Antibiotics & $207(92.5)$ \\
\hline Intravenous immunoglobulin & $4(1.8)$ \\
\hline Parenteral nutrition & $6(2.7)$ \\
\hline Blood products & $12(5.3)$ \\
\hline Cardiotonics & $61(27.4)$ \\
\hline Vasopressors & $8(3.5)$ \\
\hline Mechanical ventilation & $3(1.3)$ \\
\hline Bronchoscopy & $5(2.2)$ \\
\hline Surgical drainage of the pleural space & $6(2.7)$ \\
\hline Surgical lung decortication & $2(0.9)$ \\
\hline
\end{tabular}

The average length of intensive treatment was 2.8 days, and the average total length of hospital treatment was 9.5 days. All children treated for pneumonia had a successful outcome.

\section{DISCUSSION}

Pneumonia is the largest single cause of death in children aged $<5$-years (1). Global estimates of the annual incidence of pneumonia in children under 5 years of age, range from 120 to 160 million episodes per year, with more than $99 \%$ occurring in resource-limited countries $(1,2,3)$. In high-income countries it is one of the most common reasons for clinic attendance and hospitalization in this age group (5). Furthermore, pneumonia in children increases the risk of developing 
chronic pulmonary disorders in later adult life (6). In our study, during one-year period about 224 children were hospitalized for pneumonia. Almost half of them were infants, and more than $80 \%$ of children were under five years of age. This age distribution correspond to the usual distribution of lower respiratory tract infections in children and distribution of pneumonia in the general (5). Although this study analyzed only pneumonia in children who required hospitalization, our local results are consistent with the epidemiological studies from different geographic areas $(4,5,6)$. In addition to age, gender is also reported as a risk factor for distribution of respiratory infections and pneumonia. According to current published data boys aged under 5 years more often have pneumonia than girls, whereas at school age no gender differences in the occurrence of pneumonia. Unexpected, our study showed a high incidence of pneumonia in boys at all ages (2-6). Possible that this declared distribution primarily refers to previously healthy children, whereas in our study, were dominated children with one or more underlying chronic diseases. Few of them had recurrent pneumonia.

Recurrent pneumonia as a diagnostic and therapeutic problem, conventionally is associated with structural damage of the lower respiratory tract, or to immunodeficiency, that is linked with a number of chronic diseases $(7,8)$. Treatment of children with chronic diseases posing new challenges for health services. The need for health care services for these children is up to 20 times higher than for healthy children, depending on the underlying disease (9). Children with underlying chronic diseases require more frequently hospital admissions and longer treatments for their lower tract respiratory infections, and are more inclined to respiratory failure (10). Studies showed that $40-70 \%$ of children treated in intensive care units come from the group of children with underlying chronic diseases $(9,10)$. A number of chronic diseases favor the occurrence of recurrent or persistent pneumonia such as: congenital heart defects, cystic fibrosis, neuromuscular diseases, immunodeficiency, anatomic variations lungs, etc. Among children with pneumonia and underlying cause of disease, children with neurodevelopmental disorders are the most dominant ones (10). Chronic diseases have been identified as risk factors in our patients too. Besides neurodevelopmental disorders, the most common was anemia. Almost half of children with pneumonia were anemic. Anemia is a significant etiological factor which can cause difficulties in breathing, acute respiratory failure, and recurrent respiratory illnesses in children. Anemia has a proved influence on children's immune system and increases a predisposition to infection (11).

Pneumonia, especially when recurrent, is linked to future chronic lung disease, which highlights impor- tance of timely and correct diagnosis. (6). Thus, interventions that reduce pneumonia and acute lower respiratory infections have both short and long-term benefits. Clinicians have traditionally used radiography as the gold standard in the diagnosis of pneumonia. There is disagreement over whether a chest X-ray should be an index test. Current guidelines on childhood pneumonia do not advocate mandatory a chest X-ray outside of hospital settings. Furthermore, their interpretation is subjective often resulting in additional diagnostic variability. However our local current algorithms still respect radiography as the gold standard of diagnosis and monitoring treatment of pneumonia. For a correct diagnosis sometimes there is a needfor the chest computed tomography scans (4). For our patients radiographically confirmed pneumonia was the selection criteria, but the course of treatment in some complicated cases required a CT scan in addition.

Early recognition and appropriate treatment of imminent respiratory failure is crucial for the reduction of risk for long-term complications (12). Monitoring of vital parameters of endangered patient is integral part of intensive supervision and treatment. Depending on the equipment modern monitoring may include monitoring a range of vital parameters. The most important are: pulse rate, respiratory rate, blood pressure, body temperature. Pulse oximetry is simple and non-invasive assessment methods therefore in the current literature means as the fifth vital sign, practically unavoidable in rapid assessment of respiratory function. Pulse oximetry observed isolated, can be unreliable. The basic test that can determine level of patients respiratory inadequacy are gas analyses and they are a mandatory part of the monitoring for patients with threatening respiratory failure (13). General condition and recognized signs of dyspnea and hypoxia are determinants of selection children who require hospitalization. The highest morbidity and mortality rates of pneumonia economic and health underdeveloped areas where diagnostic capabilities are limited. The predictive value of specific clinical symptoms and signs, has already been investigated, especially in order to identify hypoxemia in children. In all these studies, tachypnea and signs of dyspnea significantly correlated with hypoxemia in children $(14,15)$. Therefore, thelain current World Health Organization (WHO) recommendations for the diagnosis and treatment of pneumonia in children is generally based on clinical parameters (16).

Community healthcare workers often diagnose pneumonia based on medical history and physical examination (respiratory rate, signs of dyspnea, auscultatory findings). According to the $\mathrm{WHO}$, pneumonia can be recognized by cough or breathing difficulties, and 
age-adjusted tachypnea are sufficient for diagnosing mild-to-moderate pneumonia (16). In our study clinical findings at admission were characterized by tachycardia, tachypnea and low oxygen saturation. These are unambiguous clinical signs of dyspnea, which correlate well with hypoxemia assessed by pulse oximetry. Gas analysis have confirmed moderate hypoxemia so that clinical parameters, pulse oximetry and gas analysis were matched according to the type of hypoxemic respiratory failure. Previously studies suggest that gas analysis, especially confirmed hypoxemia, correlates well with radiologically verified pneumonia in children (14).

Current studies determining the etiology of pneumonia vary substantially with respect to factors that influence the diagnosis and ascribed microbial etiology. These include case definitions, use of and interpretation of chest x-rays, peripheral blood white cell counts, and inflammatory markers, depth of investigations, facility type, and patient characteristics. Consequently, studies describe different frequency and types of pathogens associated with pneumonia. Recent studies based on modern microbiological diagnostics stated that in more than $25 \%$ of children with pneumonia causative agent does not identify; in $25 \%$ proved by the viral etiology in $25 \%$ of bacterial and $25 \%$ of patients have a mixed infection (17). Major viral causes of pneumonia in infants and children include respiratory syncytial virus, influenza, adenoviruses, parainfluenza and human metapneumovirus. While viruses are the predominant cause of pneumonia, especially in the young children, respiratory bacterial pathogens are most often implicated in childhood deaths from pneumonia (18). The predominant bacterial pathogen is Streptococcus pneumoniae, which dominates across all age groups, but other important pathogens include Haemophilus influenzae, Staphylococcus aureus and, in older children, Mycoplasma pneumoniae (4). For children with impaired immune systems pneumonia is usually caused by viruses, bacteria and fungi (19).

Non-specific markers of inflammation (erythrocyte sedimentation rate, C-reactive protein and leukocytes) are not very important in distinguishing children with viral and bacterial pneumonia. However, the very high value of individual inflammatory markers are rarely seen in viral infections. C-reactive protein greater than $10 \mathrm{mg} / \mathrm{l}$ is significant for bacterial pneumonia (20, 21, 22). Etiological studies of pneumonia vary depending on the age, season, climate, epidemic trends, and status of immune system in children. Our results are different than most of published studies, which generally report a typical pathogens, separately for individual categories: community-acquired pneumonia; hospital or pneumonia in immunodeficient patients. In our study microbiological findings indirectly talking about immune status of patients with regard to agents more appropriate for the progressive complicated pneumonia and pneumonia in immunodeficient patients. The focus is on the antimicrobial therapy when appropriate, correcting hypoxemia, fluid and nutritional management, treatment of co-morbidities, and close observation for developing complications. National treatment guidelines exist, but there is wide variability in managing pneumonia, even in resource-rich countries. Preventing pneumonia in children is an essential component of a strategy to reduce child mortality. Important factors identified for increasing the risk of pneumonia include overcrowding, access to clean water, malnutrition, anemia, young maternal age, low birth weight, and exposure to tobacco smoke and other environmental pollutants. Protect children from pneumonia includes promoting exclusive breastfeeding and adequate complementary feeding. Vaccines, such as pertussis, measles, and more recently haemophilus influenzae and pneumococcal, have reduced the worldwide incidence of pneumonia. However, the benefit from population vaccination programs is not always uniform, which although having significantly reduced pneumonia rates in target and some older age groups. There seems to be a viral etiological component in at least half of all pneumonia that require hospitalization. Respiratory sincytial virus is a dominant viral cause, but the role of other viruses should not be neglected. Significant role could have started program of prevention respiratory syncytial virus infection for the most vulnerable child categories.

\section{CONCLUSION}

The aim of this study was to show epidemiologic, etiologic and clinical characteristics of pneumonia in hospitalized children at the Pediatric hospital Tuzla.

The incidence of pneumonia was significant, especially in infants. Almost half of children with pneumonia were infants, and three quarters of treated children were under five years of age. The boys were leading in all age groups. A significant number of children had one or more predisposing risk factors. Children with underlying chronic diseases required more frequently hospital admissions and longer treatments for pneumonia, and are more inclined to respiratory failure. Among them, children with neurodevelopmental disorders were the most dominant. Besides neurodevelopmental disorders, almost half of children with pneumonia were anemic. Clinical signs, gas analyses and oxygen saturation correlated well with the radiological findings, also well correlated with hypoxemic type of respiratory failure. The most frequently isolated pathogens were Staphylococcus aureus, Klebsiella sp. and Pseudomonas aeruginosa, which are different than most of published 
studies with generally reported a typical pathogens. That emphasizing the severity of disease and immune status of children. The management of pneumonia in children has to follow general pediatric principles. Special attention should be given to risk categories.

\author{
Abbreviations \\ pCO2 - partial pressure of carbon dioxide \\ pO2 - partial pressure of oxygen \\ WHO — World Health Organization
}

\title{
Sažetak
}

\section{KARAKTERISTIKE PNEUMONIJA KOD HOSPITALIZOVANIH NA PEDIJATRIJSKOJ KLINICI TUZLA}

\author{
Hadžić Devleta, Zulić Evlijana \\ Klinika za dječije bolesti, Univerzitetski klinički centar Tuzla, Tuzla, Bosna i Hercegovina
}

Uvod: Pneumonija je najteža zapaljenska bolest donjih disajnih puteva, uzrokovana brojnim i različitim mikroorganizmima. Pojavljuje se u svim starosnim grupama, češće kod dece uzrasta do 5 godina, te kod osoba sa hroničnim bolestima i oštećenjima imunološkog statusa.

Cilj rada: je bio da se prikažu epidemiološke, etiološke i kliničke karakteristike pneumonije kod hospitalizovane dece.

Pacijenti i metode: Studijom je obuhvaćeno 224 dece hospitalizovanih na Klinici za dečije bolesti Tuzla, u jednogodišnjem periodu, sa radiološki dokazanom pneumonijom.

Rezultati: Skoro polovina dece sa pneumonijom $(46,4 \%)$ bila su odojčad, a $82,1 \%$ pacijenata bili su mlađi od 5 godina. Dečaci su prednjačili u svim starosnim grupama. Značajan broj pacijenata imao je jedan ili više predisponirajućih faktora. Klinički znaci, nalaz

\section{REFERENCES}

1. Chang AB, Ooi MH, Perera D, Grimwood K. Improving the Diagnosis, Management, and Outcomes of Children with Pneumonia: Where are the Gaps? Front Pediatr. 2013; 1:29.

2. Walker CL, Rudan I, Liu L, et al. Global burden of childhood pneumonia and diarrhoea. Lancet. 2013; 381(9875): 1405-16.

3. Graham SM. Child pneumonia: current status, future prospects. Int J Tuberc Lung Dis. 2010; 14(11): 1357-61.

4. Lynch T, Bialy L, Kellner JD, et al. A Systematic Review on the Diagnosis of Pediatric Bacterial Pneumonia: When Gold Is Bronze. PLoS One. 2010; 5(8): e11989.

5. Dennehy PH. Community-acquired pneumonia in children. Med Health R I. 2010; 93(7): 211-5.

6. Lee GE, Lorch SA, Sheffler-Collins S, Kronman MP, Shah SS. National hospitalization trends for pediatric pneumonia and associated complications. Pediatrics.2010; 126(2): 204-13.

7. Saračević E. Rekurentne pneumonije u detinjstvu, diferencijalna dijagnoza. U: Aberle N, urednik.1. izd. Sekundarna prevencija u pedijatriji. Slavonski Brod: Hrvatsko pedijatrijsko drštvo; 2007. str. 70-3. gasnih analiza i pulsna oksimetrija, bili su u korelaciji i po tipu hipoksemijske respiratorne insuficijencije. Najčešće izolovani uzročnici bili su Staphylococcus aureus, Klebsiella sp. i Pseudomonas aeruginosa. Prosečna dužina intenzivnog tretmana bila je 2,8 dana, a prosečna dužina ukupnog tretmana 9,5 dana.

Zaključak: Karakteristike pneumonije kod hospitalizovane dece na Klinici za dečije bolesti Tuzla potvrdile su uobičajenu dobnu i delimično polnu raspodelu. Značajan broj dece imao jednu ili više hroničnih oboljenja u podlozi. Etiološke karakteristike i izolovani uzročnici više su naglašavali ozbiljnost bolesti i imunološkog statusa lečene dece. Tretman pneumonije kod dece mora slediti opšta pedijatrijska načela, a posebnu pažnju treba posvetiti rizičnim kategorijama.

Ključne reči: karakteristike pneumonija, hospitalizacija, deca, etiologija, učestalost.

8. Don M, Valent F, Canciani M, Korppi M. Prediction of delayed recovery from pediatric community-acquired pneumonia. Ital J Pediatr. 2010; 36(1): 51-57.

9. Meštrović J, Kardum G, Polić B, et al. The influence of chronic health conditions on susceptibility to severe acute illnes of children treated in PICU. Eur J Pediatr. 2006; 165(8): 526-9.

10. Hadžić D, Mladina N, Prašo M, Brkić S, Čolić B, Konjić E. Teškoće u disanju u djece sa hroničnim oboljenjima. Defektologija. 2008; 14(1): 78-83.

11. Mladina N, Hadžić D, Latifagić A, Konjić E, Bazardžanović M, Mladina Ž. Anemije i infekcije donjih dišnih puteva u djece. Defektologija. 2008; 14(1): 84-93.

12. Carrillo AA, Martinez GA, Salvat GF. Recognition of the child at risk of cardiopulmonary arrest. An Pediatr (Barc). 2006; 65(2): 147-53.

13. Dobyns E. Assesment and monitoring of respiratory function. In: Fuhrman BP, Zimmerman J, editors. Pediatric critical care. Philadelphia: Mosby Elsevier; 2006. p. 530-5.

14. Lodha R, Bhadauria PS, Kuttikat AV, et al. Can Clinical Symptoms or Signs Accurately Predict Hypoxemia in Childran with Acute Lower Respiratory Tract Infections? Indian Pediatr. 2004; 41(2): 129-35. 
15. Rahnamai MS, Geilen RP, Singhi S, Van den Akker M, Chavannes NH. Which clinical signs and symptoms predict hypoxemia in acute childhood asthma. Indian J Pediatr. 2006; 73(9): 771-5.

16. Rudan I, Boschi-Pinto C, Biloglav Z, Mulholland K, Campbell H. Epidemiology and etiology of childhood pneumonia. Bull World Health Organ. 2008; 86(5): 408-16.

17. Gilani Z, Kwong YD, Levine OS, et al. A literature review and survey of childhood pneumonia etiology studies: 2000-2010. Clin Infect Dis. 2012; 54 (suppl 2): S102-8.

18. Chang AB, Clark R, Acworth JP, Petsky HL, Sloots TP. The impact of viral respiratory infection on the severity and recovery from an asthma exacerbation. Pediatr Infect Dis J. 2009; 28(4): $290-4$.

\author{
Correspondence to /Autor za korespondenciju \\ Devleta Hadžić \\ Univerzitetski klinički centar Tuzla, \\ Klinika za dječije bolesti \\ Trnovac bb, 75000 Tuzla \\ Bosna i Hercegovina \\ 0038735303733 \\ e-mail: devletahadzic@yahoo.com
}

19. Esposito S, Marchese A, Tozzi AE, et al. Bacteremic pneumococcal community-acquired pneumonia in children less than 5 years of age in Italy. Pediatr Infect Dis J. 2012; 31(7): 705-10.

20. Tumgor G, Celik U, Alabaz D, et al. Aetiological agenst, interleukin-6, interleukin-8 and CRP concentrations in children with communitiy-acquired pneumonia. Ann Trop Pediatr 2006; 26(4): 285-91.

21. Almirall J, Bolibar I, Toran P, et al. Contribution of C-reactive protein to the diagnosis and assesment of severity of communitiy-acquired pneumonia. Chest. 2004; 125(4): 1335-42.

22. Lagerstrom F, Engfeldt P, Holmberg H. C-reactive protein in diagnosis of comunity-acquired pneumonia in patient in primary care. Scand J Infect Dis. 2006; 38(11-12): 964-9. 